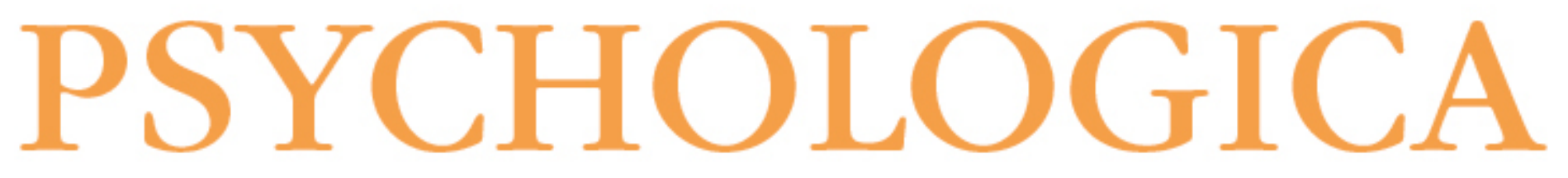

\title{
Are employment relations in Europe based on trust? The employee representative perspective
}

\author{
Autor(es): $\quad$ Elgoibar, Patricia; Munduate, Lourdes; Medina, Francisco J.; Euwema, \\ Martin C.
}

Publicado por: Imprensa da Universidade de Coimbra

URL

persistente: URI:http://hdl.handle.net/10316.2/5596

Accessed : $\quad$ 26-Apr-2023 07:03:24

A navegação consulta e descarregamento dos títulos inseridos nas Bibliotecas Digitais UC Digitalis, UC Pombalina e UC Impactum, pressupõem a aceitação plena e sem reservas dos Termos e Condições de Uso destas Bibliotecas Digitais, disponíveis em https://digitalis.uc.pt/pt-pt/termos.

Conforme exposto nos referidos Termos e Condições de Uso, o descarregamento de títulos de acesso restrito requer uma licença válida de autorização devendo o utilizador aceder ao(s) documento(s) a partir de um endereço de IP da instituição detentora da supramencionada licença.

Ao utilizador é apenas permitido o descarregamento para uso pessoal, pelo que o emprego do(s) título(s) descarregado(s) para outro fim, designadamente comercial, carece de autorização do respetivo autor ou editor da obra.

Na medida em que todas as obras da UC Digitalis se encontram protegidas pelo Código do Direito de Autor e Direitos Conexos e demais legislação aplicável, toda a cópia, parcial ou total, deste documento, nos casos em que é legalmente admitida, deverá conter ou fazer-se acompanhar por este aviso.

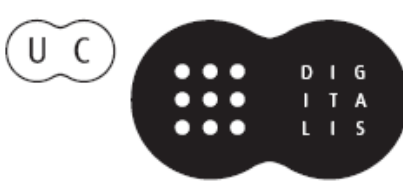




\section{NÚMERO 55}

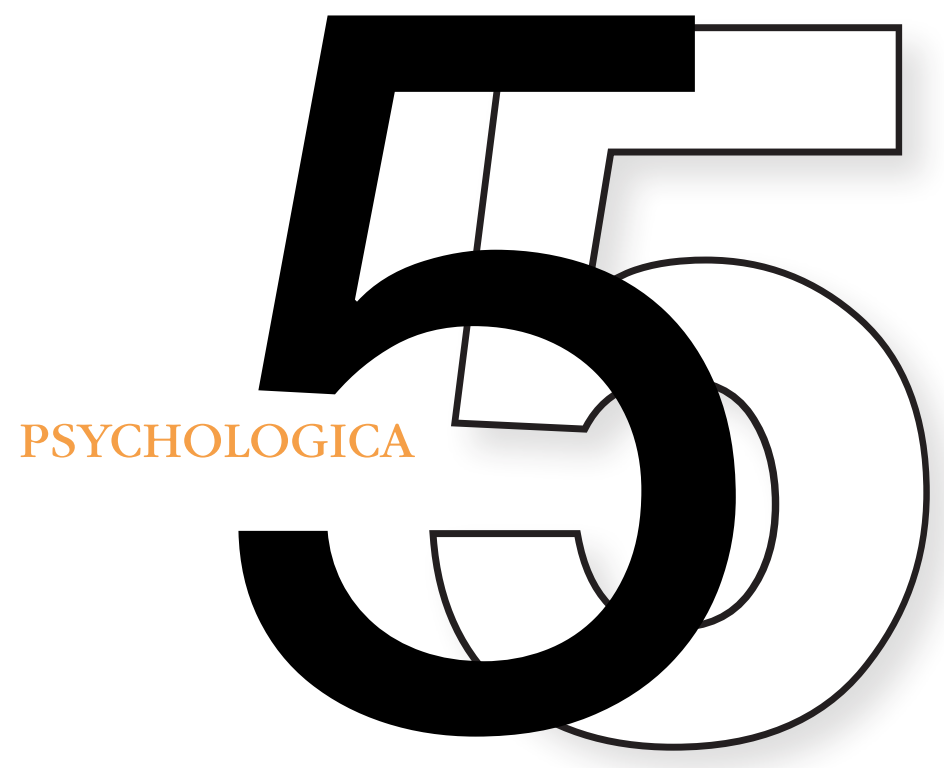

PSICOLOGIA DAS

ORGANIZAÇÕES

DO TRABALHO E DOS

RECURSOS HUMANOS 


\title{
Are employment relations in Europe based on trust? The employee representative perspective
}

\begin{abstract}
Patricia Elgoibar', Lourdes Munduate², Francisco J. Medina² \& Martin C. Euwema ${ }^{3}$
Numerous researchers from various disciplines agreed that trust has important benefits for organizations (Dirks \& Ferrin, 2001) and their members (Kramer, 1999). However we sometimes find not that easy to achieve the appreciated and desired trust in employment relationships. In this paper, firstly we define the concept of trust and its importance in the European industrial relations. Secondly, we explore how employee representatives (ER) around Europe perceive the relationship with management as well as with co-workers, focusing on trust. Finally, we will conclude with a discussion and some practical recommendations that can help ERs to increase trusty relationships, improving the capacity to participate in the decision making process and leading to a more constructive conflict management.
\end{abstract}

KEY-WORDS: Trust, employee representatives, industrial relations, management and co-workers.

Relations between employers, trade unions, and employees in Europe are rapidly changing (Euwema, Nauta, Munduate, Medina, Martinez-Pecino \& Viemose, 2008). The new competitive demands for organizations, the globalization process and economic turbulence, lead to new organizational relations in which employee representatives (ER) play a central role. ERs are typically employees (part-time or full-time) who play a role as representative within the company. They represent their colleagues in different types of organizational conflicts and decision making processes with the management.The ability of ERs to find out and negotiate new organizational arrangements is essential to support these changes (Rocha,

\footnotetext{
1 University of Seville, Spain and University of Leuven, Belgium - patriciaelgoibar@gmail.com

2 University of Seville, Spain

3 University of Leuven, Belgium
}

The work described in this article is partially supported by a grant from the European Commission: Employment, Social Affairs and Equal Opportunities DG (Project Ref.VS/2010/0376), the Spanish Ministry of Science (Project Ref. PSI 2008/00503 and Project Ref. PSI2008-00502) and by the Andalusia Council of Labour Relations (CARL). The authors would like to thank the participating unions for their assistance in data collection. 
2010). In fact, they play a critical role in shaping and mediating the relationship between managers and employees (Bacon \& Blyton, 1999; Stuart \& Lucio, 2002).

Given the importance of trust in the relations between ER and management as well as ER and co-workers, there is a surprising lack of studies on this issue. The cultural differences in power, history and structure of labour relations in Europe (Euwema et al., 2008) could predict differences around the European countries. In this paper we analyze trust in the relations between ER and a) management and b) co-workers in 8 European countries (Belgium, Denmark, Estonia, Germany, Holland, Portugal, Spain and United Kingdom).

\section{Trust in the workplace}

Following Rousseau, Sitkin, Burt and Camerer (1998, p.395), "trust is a psychological state comprising the intention to accept vulnerability based upon positive expectations of the intentions or behaviour of another". Agreeing with this idea, we define trust as the expectation that the other party will cooperate in the future (Pruitt \& Carnevale, 1993). The mutual trust between ERs and both management and co-workers is an essential tool to understand the industrial relations in the different countries and the role of ER in them.

Interpersonal trust in the workplace has shown to have a strong and robust influence on a variety of organizational phenomena including job satisfaction, stress, organizational commitment, productivity and knowledge sharing (Moradian, Renzl \& Matzler, 2006; Kramer, 1999; Levin \& Cross, 2004). Trust is an essential factor to build intraorganizational relations and cooperation (Coleman, 1990; Fukuyama, 1995; Putman, 1993; Kramer \& Tyler 1996). Trust leads to more collaborative negotiation behaviours and more integrative negotiation outcomes in interpersonal and intergroup negotiations (Lewicki, McAllister \& Bies, 1998; Ross \& LaCroix, 1996; Taylor, 1989).

Given the competitive challenges of organizational growth, globalization, strategic partnerships (Martinez Lucio \& Stuart, 2002) and multicultural relations (Cox \& Tung, 1997), trust has become a critical competence within organizations (Lewicki et al., 1998). The trusting qualities of the relations between parties - ER (employee representatives), management, co-workers and trade unions - are critical for successful collaboration (Sheppard, 1995).

\section{Trust and culture}

Hofstede's study (1980) concluded that trust is established upon the societal norms and values that guides people's behaviour and beliefs. Also the process 
trustors use to decide whether and whom to trust (Donay, Canon, Mulley, 1999) and how to use the information to make decisions (Triandis, 1972) depending on societal cultures. Taking it together we predict that societal culture matters in trust relationships because they affect the interpersonal communication of information (Kramer \& Cook, 2004).

When it comes to industrial relations, Europe can't reasonably be analysed as a homogeneous entity but must be recognised as comprising a diversity of traditions and national cultures (Hyman, 1995). In that sense, we can find many differences between the traditions of East and West, and North and South. The crossnational differences were constructed after 1945 and are of obvious importance for the understanding of more recent trends in the study of industrial relations in Europe (Hyman \& Ferner, 1994). Following the division of Hyman (1994) we divide the industrial relations in Europe in two different models. First, the "Nordic model" mainly in the Scandinavian countries, is based on cooperative and trusty relations within organizations, where decisions are made by management and union representatives with balanced power. Second, the "Mediterranean model" characterized by authoritarian employers, where decisions are made unilaterally by management. These two models are different mainly in two aspects: power distance between managers and ER, and historical background. In the following pages we analyze how trust (between ERs and managers and also with co-workers) would differ in these labour relationships traditions according to these aspects.

Power distance is defined as "the extent to which the less powerful members of institutions and organizations within a country expect and accept that power is distributed unequally" (Hofstede, 1997, p. 28). This definition closely resembles the more recent definition by House and colleagues (2004, p. 537) who define power distance as "the degree to which members of an organization or society expect and agree that power should be shared unequally". As an example of the countries involved in the study, the results of Hofstede's study (2004) identify Spain as a high power distance (HPD) country (score: 5.52) and Denmark as a low power distance (LPD) country (score: 3.89 ) (the highest value is Morocco - 5.80 - and the lowest Denmark - 3.89-). This is related to the hierarchical structure within Spanish organizations and a tendency to keep a certain distance in power in organizational settings (see for example historical revision of labour relationship in Spain by Munduate, Ganaza, Alcaide and Peiró, 1994). Van Oudenhoven and colleagues (1998) identified that LPD employees prefer the consultative management style, which provides more balance between the most and the least powerful. Thus, power distance will play an important role in trust relations within organizations. In HPD countries trust between management and ERs will be lower than in LPD countries. However, in HPD countries trust between co-workers and ERS will be higher than in LPD. 
Furthermore, the historical tradition can have an effect on the level of trust that can be found in the industrial relations in the studied countries. As an example we show the difference between the historical tradition of Spain and Denmark. Munduate and colleagues point out (1994, p.104) "Spain has evolved from a rigid society, with organizations managed in an authoritarian style, as befitted a dictatorial regime, to a more tolerant, creative, and innovative society". Due to the dictatorial regime, negotiation between unions and companies as well as the right to carry out industrial actions within organizations were prohibited until democracy was established, in 1978. Thus, a tradition of adversarial relations between ERs and management predominates in Spain (Munduate, Luque \& Barón, 1997; Rocha, 2010). On the other hand we find Denmark, where decentralization is a characteristic of organizations (Knudsen \& Bruun, 1998). ERs are able to influence corporate strategy and development (Rocha, 2009) being strongly involved in the governance (Kristensen \& Rocha, 2006). By participating in strategy construction and linking it to their experiences at shop-floor level, ERs become essential partners to management in the development of the firm (Rocha, 2010). In other words, feeling that both groups (management and workers) are one group (organization) working together, implies a trust relationship, which leads to a more collaborative way of decision making. Thus, in countries with an adversarial tradition we will find less trust relationships between management and ERs than in countries with a collaborative tradition.

\section{Trust and distrust}

Evidence exists that trust is not a one-dimensional construct (Deutsch, 1960; Luhmann, 1979; Cacioppo \& Berntson, 1994; Lewicki, McAllister \& Bies, 1998). Organizations can not be grouped on a single continuum of high or low trust, but as some authors (Lewicki et al., 1998) suggest, trust and distrust often appear together. Distrust appears mainly when the other part violates psychological contract or formal agreements. In the case of organizations, distrust usually appears in downsizing, corporate restructuring situations or when the information is partial or invalid (Rousseau, 1995; Morrison \& Robinson, 1997).

Following Lewicki and colleagues (1998) model "Integrating trust and distrust", trust and distrust are separate dimensions that combine different social realities (see Figure 1). To check the described relations within European organizations we conduct a cross-cultural qualitative study. In this study we will analyze if the relationship between management and co-workers with ER are based on trust/distrust as well as the cultural and organizational differences between them. 


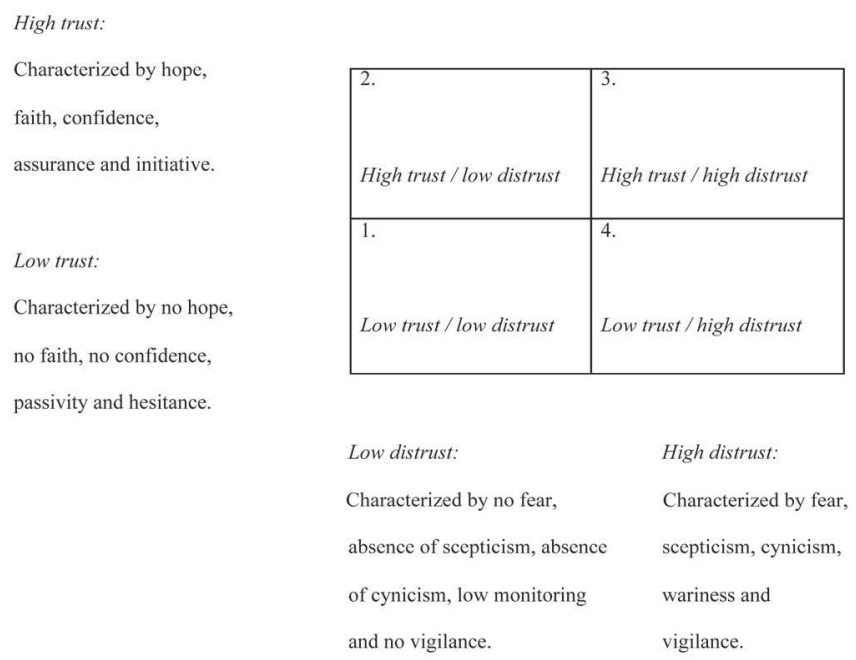

Figure 1: Integrating trust and distrust: Alternative social realities. Lewicki, McAllister and Bies (1998)

\section{Method}

Data were collected through structured interviews and focus groups in Belgium, Denmark, Estonia, Germany, Holland, Portugal, Spain and United Kingdom. The figure below (table 1) shows the quantity of data collected in each country.

The research team in each country contacted ERs, management, union leaders and professors on this area through the main trade unions and labour relation councils, to encourage them participate voluntarily in the interviews and focus groups. Firstly the interviews were carried out and after analyzing the collected data, focus group meetings were held in each country in order to discuss and validate the previous results. The results from the interviews were discussed. The participants in the focus group were not the same as the ones taking part in the interviews. Thus, we could validate the previous results as well as get more data from the opinions of a new range of participants.

For the development of the present study, we asked interview participants: "How to improve the relationship and build trust between employee representatives 1.) and management; 2) and co-workers?". Researchers measure trust as multi-item scales, in line with the tradition in psychology and sociology not to rely on single item variables, due to robustness considerations (Bijlsma \& Koopman, 2003). However, evidence exists (Wanous \& Reichert, 1997) that single item measurements can be as robust as scale measures. 
Table 1: Data collected in the 8 European countries.

260

\begin{tabular}{l|l} 
Country & Data collected \\
\hline Belgium & 7 interviews + focus group (8 participants) \\
Denmark & 10 interviews + focus group (6 participants) \\
Estonia & 11 interviews \\
Germany & 10 interviews + focus group (6 participants) \\
Holland & 10 interviews + focus group (9 participants) \\
Portugal & 8 interviews + focus group (10 participants) \\
Spain & 11 interviews + focus group (8 participants) \\
U.K. & 12 interviews \\
\hline Total & 79 interviews + 6 focus group
\end{tabular}

\section{Results}

According to the theoretical framework, we can confirm that trust in industrial relations is related to culture. In the explored analyses we found two different cultural styles. Countries as Denmark and Holland follow the "Northern model" (Hyman, 1994) with low power distance between management and workers and high trust between them:

"The Scandinavian leadership style is based on dialog and involvement, and selfgoverning is a widespread and very important phenomenon, also in low skilled jobs. The historical reason for this tradition goes back to 1899 where a tripartite system was introduced, incorporating workers and employers union, and the government in labour market agreements. Therefore, we develop an excellent relationship based on mutual respect and trust" (Trainer, male, Denmark).

Some countries such as Spain and Portugal follow the "Mediterranean model" (Hyman, 1994) with high power distance between management and workers and low trust between them:

“Management doesn't consider us part of the decision making process. If they don't trust us, we can't trust them. It's a cultural matter here: management is management" (ER, male, communication sector, Spain).

In other countries such as Belgium, Estonia and U.K. we found diversity of opinions and we can't conclude a clear trend about trust in relations. They depend basically on the sector and/or organization. An example of two contrarian viewpoints about trust in organizational relationship in the same country and sector can be found in Estonia: 
"The management totally trusts me as employee representative. We share information we, co-operate to make the situation better" (ER, female, education sector, Estonia).

"My relationship with the management is difficult and the management essentially trusts me never and not in any matters. It's not possible to increase trust" (ER, female, education sector, Estonia)

On the other hand, following the model of Lewicki and colleagues (1998) the main situations that we found in the relations between management and ERs in Europe are a) "high trust/ low distrust"(cell 2) and b) “low trust/high distrust" (cell 4) (see figure 1):

a) High trust/low distrust (cell 2): A characteristic of countries which the Scandinavian model, where the different groups focus on maintaining collaborative relations and low power distance relations. These conditions reflect "promotive interdependence" and cooperation (Deutsch, 1962).

"ERs function as a sparring partner for the management. There is an emphasis on the fact that the WR is to be included in the process leading up to decisions" (ER, male, education sector, Denmark).

b) Low trust/high distrust (cell 4): A characteristic of countries which follow the Mediterranean model, where the management makes decisions unilaterally without the collaboration of workers and the power distance is high. Under this model actors have no reason for confidence with others and ample reason for wariness and watchfulness (Lewicki et al., 1998).

"Distrust not trust is what you can find in the relation between management and workers. Distrust exists because information isn't transparent and is biased"(ER, female, education sector, Spain).

In the next paragraphs we explain more in depth the main characteristics of trust relations between management and ER and between co-workers and ERs.

\section{Trust with management}

As mentioned previously trust in management is highly related to the societal culture, specifically measured by the power distance between management and ER (Elgoibar, Euwema, Munduate, Medina \& Viemose, 2011). Elgoibar and colleagues (2011) by analyzing the conflict behaviour followed by ERs concluded that in societies characterized by low power distance (i.e. Denmark) the relation between ERs and management is more cooperative. In contrast, in countries with high power distance (i.e. Spain) the relation between these two groups is more competitive. However, within the different cultures we can appreciate 
that there exists differences in relationship and trust level when we focus on the organizations.

In that sense, respecting the ERs' opinion and encouraging them to participate in the decision making improves open communication and mutual respect within the organization.

"Trust will increase if management gives us the choice to decide, but if they continue providing uncompleted information, we cannot trust" (ER, female, services sector, Spain).

"The most promising way to build up trust is stressing communication"(ER, male, industrial sector, Germany).

"Trust depends on the attitude of the management - if exists an intention to solve real problems or not. The resolution of problems in the workplace improves the operation of the company and increase productivity"(Union leader, female, Portugal).

"If participation does not exist from both parties trust never will be established. It is necessary to create the right to participation. Participation is weakened because companies do not see ERs as active actors in solving problems"(ER, male, transport sector, Portugal).

"Successful relations with management are dependent on openness but also access to reliable and up-to-date information - the latter is not always guaranteed" (Union leader, female, metal industry, Germany).

"You can sense the attitude of "you are not really welcome here" in meetings with management"(ER, female, commercial sector, Estonia).

Some countries following a cooperative approach such as Holland, where the absence of strikes is an indicator of trust between management and ER, we find organizations that still keep a competitive relationship.

"Although trust with management is sufficient, we always keep a "we against them" perception"(Union leader, female, Holland).

According to this issue, some ERs express the differences between countries from a legal approach:

"Law doesn't guarantee union rights as it does Denmark or Germany. Without European framework of rights and regulations, trust is always vulnerable and unlikely to be developed"(ER, male, education sector, U.K.).

"Spanish management don't obey the law in terms of information sharing and consulting!"(Union leader, male, Spain).

Focusing on an economical approach, the financial situation of the sector and company leads also to differences in trust: 
"Trust between us and management is very poor now, due to the crisis in our activity sector. Trust has been undermined in the last few years through the public expenditure cuts, salary and resource cuts..." (ER, male, construction company, U.K.).

"Trust has decreased in the last times due to the much insecurity and ambiguity"(ER, male, flight company, Holland).

However there are also some cases, where the crisis has enhanced cooperation and information sharing between management and co-workers:

"Information sharing and close relationship with management has increased during the crisis because they need our signature on redundancy plan. But this is not the traditional way of relation with the management. Normally they don't pay any attention to us and when things are going wrong, they realized that they need our support" (Trade union leader, male, Spain).

Finally, we should point out that some participants (mainly in countries with a more competitive relationship) feel that being too close to the management could be dangerous.

"Cooperation is necessary but maintaining independence otherwise people will hold it against"(ER, male, electronic sector, Belgium).

"We can be friendly with management but preserving our ability to attack"(ER, male, financial sector, Belgium).

"The relationship between me and the management could be described in one word: opposition. I am never trusted in anything. And I don't even want to do anything with the director to increase trust, not even talk to her"(ER, female, education sector, Estonia)

In contrast, in more cooperative countries this vision is very different:

"The overall tendency is to view WR as a partner, not an enemy. This is in accordance with the way the employees perceive things. Most employees do not see themselves as opposition to the management" (Executive committee, male, Denmark).

"Our company has introduced a new form of employee participation: 'Participating together'. Now our worker council is always involved in application procedures of top managers. For example, we were involved in selecting a new HR-director" (ER, male, public services sector, Holland).

In conclusion, relations between management and ERs in Europe are influenced by: culture (power distance and historical background); information sharing and capability to make decisions cooperatively; and economical situation within the organization and the sector. 


\section{Trust with co-workers}

After exploring the results, we can conclude that among the European countries studied overall co-workers trust their ER and vice-versa (from the perspective of ER, union leaders, experts and management). How do ERs get trust of their coworkers? How do ERs perceive this trust? Open communication and daily support to co-workers seem to be the key points for keeping a trusty relationship between them. Generally, results show that ERs perceive trust and support from their coworkers, and that this is a result of their day to day work on the shop floor. From the following comments we can get and overview about this relationship within the organizations in the participating countries.

"My fellow employees always trust me in all matters" (ER, female, education sector, Estonia).

"A good relationship between the ERs and the colleagues is implemented through a lot of open communication"(ER, male, private sector, Germany).

"Be honest, don't set false expectations. People appreciate this honesty"(Legal advisor, male, Belgium).

"We can have trustful relations with management, as long as it remains clear that we are there to protect the interest of workers. That is the bottom line" (Trade union trainer, male, Belgium).

"Communication on a regular basis and in many forms is an important factor in building trust" (Executive committee, male, Denmark).

For achieving fluent and up to date communication with the co-workers, ERs use newspaper, flyer and new communication media system (i.e. facebook and twitter):

"Communication is easier in the last years due to social media. Social networks as Facebook and Twitter make possible an immediate channel with co-workers" (Consultant, female, Holland).

However, some participants pointed out that the most important is going to the shop floor and speak directly to your co-workers:

"Going on the floor to speak directly to the workers is the most effective communication way, although this could be more stressful. It's good because the workers see you working, I ask them about their problems and needs, inform about my actions and get feedback"(ER, male, public services, Spain).

In that sense, in "communication in small organizations is easier than in the big ones" (ER, male, transport industry, Portugal)

Therefore, in some companies they are starting to create social network systems: 
"We do communicate on a regular basis, via intranet and newsletters. But that's all passive; it is information but no communication. That's why we are now trying to work with networks; we discuss things with 20 interested employees and ask them to tell things further so that everybody knows and is involved"(ER, male, engineering company, Holland).

Furthermore, support is an essential motivator for ERs (Elgoibar, Euwema, Munduate, Medina \& Viemose, 2011). Their behaviour and relationships are related to the support they get from their co-workers and the union structure. In that sense, it is important that ERs keep always in mind their representation role, and don't think unilaterally:

"You need to have a group that trust you. So even when I am talking one on one with a manager, I always acknowledge that I am only representing a group. You need to have a good team of unionist, a good operation structure to perform trade union work: social and union support" (ER, male, electronic industry, Belgium).

"Good relationship with co-workers gives me freedom to act" (ER, female, commercial sector, Portugal)

Participants perceive that co-workers trust ERs basically thanks to the information they get from the co-workers which gets increased with the informal daily meetings.

"We handle with confidential information on individuals. Social and family issues are encountered by ER. Thus, we need to be trust by our co-workers" (Trade union trainer, female, Belgium).

There is a lot of trust amongst workers. I am very much aware of each and everyone's problems. Actually, we trust each other so much that we talk about our personal lives. Trust is gained because if you give, people give back to you. It's one thing to be sitting in the office waiting for problems to come to you, and it's another thing to take the initiative to go out on the floor and ask them about their problems" (ER, female, communication sector, Spain).

"Is through dialog between ERs and workers that the credibility and respect are fostered among them. Relationship should be transparent so that dialogue can be fostered and established" (Union leader, male, Portugal).

However, in some countries the election system also shows the level of trust among co-workers by being elected not only by the affiliated worker, but by the totality of workers in the company:

"Workers show us their trust because ERs are elected on a system of double representation. They are elected in two different ways: a) Union ER: Within the company, union ER are elected by union members; b) Company committee: All 
the workers within the company are able to directly elect their ER. On one hand, this does not benefit the union affiliation because everyone can choose their ER; but on the other hand it's a good system because representatives are compelled to justify their actions to all their workers"(Union leader, male, Spain)

We can also notice that some ER face difficulties in the relation with their coworkers. This is basically consequence of a friendly relation with management.

"Sometimes workers are not easy. They tell you: you are a friend of us or you are friend of the management!"(WR, female, commercial sector, Portugal).

"Usually, what you hear on the shop floor are critics about your job when negotiations are not going well and no congratulations when things are going as planned. This is very frustrating as they don't understand that you are doing your best for them!"(ER, male, services sector, Spain)

Finally, as in the case of trust related to management, some ERs think that being too close to the co-workers could be dangerous and could damage the relation with the management.

The better the relationship with management, the worse the relationship with the employees, and vice versa" (Consultant, female, Holland).

"Getting too close to co-workers can affect your stress and your position in the company" (Legal advisor, male, Belgium).

Further below (Table 2) we include some suggestions for increasing trust with your co-workers, however, we should keep in mind that: "There is no recipe for trust. It comes from knowledge that the ER has on workers and workers on him/her and that is achieved by nurturing day to day the relationship" (ER, male, transport industry, Portugal).

\section{Discussion}

\section{Conclusions}

The main purpose of this study was to analyze the level of trust in the relations between a) management and ERs and b) co-workers and ERs. We explored the differences in trust among European countries through a cross-national study. Main findings of the study are the following:

a. Culture matters in the trust level of the relationship between management and ERs, mainly coming from the level of power distance between both groups and the historical tradition of industrial relations. 
b. Although culture is an important aspect, trust also depend on the capacity of ERs to make decisions within the organization. Although this capability is usually related to the culture of the country, it is not always that way. We find organizations where ERs opinions are respected by the management in cultures with adversarial industrial relations. This can be explained by the personal characteristics of the management or by the qualifications of the ERs.

c. In reference to the relationship maintained with co-workers, overall we find that co-workers trust their ERs around Europe and vice - versa. However, we should point out that trust between co-workers and ERs increase in cultures with an adversarial relationship with the management. The "them against us" conception encourages the collectivist spirit within co-workers and ERs, being detrimental to the relation with the management.

d. The economical situation can affect trust in relations between management and ERs. However, this effect varies according to the culture. On one side, in countries with adversarial relations, trust increases and management and ERs are getting closer in a context of economical crisis in order to "keep the organization afloat". On the other side, in countries with collaborative relations, economical crisis can make collaboration decrease, due to being obligated to sign downsizing agreements.

Taking the main conclusions together, we appreciate that not only culture but also organizational (capacity to participate in the decision making process) and economical factors (from the sector and the organization) affect the trust level that ERs have with their management and their co-workers. These factors not only are essential in the relation maintained between ER and management but also in the relation between ER and his / her co-workers.

We can state that in both kinds of relations trust is like a dog chasing its tail. On one side, more respect to the ERs participation in the decision making process will increase the level of trust that ERs have in management and vice-versa leading to more collaborative relations(Mc Evily, Perrone \& Zaheer, 2003; Gambetta, 1988; Costa, Roe \& Taillieau, 2001). In that sense, Tyler (2003), suggests that trust is a key to organizational performance because it enables voluntary cooperation. However, if management doesn't provide them with information and doesn't allow them to participate in the decision making process, trust will decrease (Dirks \& Ferrin, 2001; Levin \& Cross, 2004), being detrimental to the organizational benefits and creating adversarial relations.

Also in the case of the relation with co-workers, trust depends on information sharing (Kramer, 1999; Mooradian et al., 2006). If ERs provide their co-workers with information about their actions day to day, their co-workers 
will increase the trust in them (Bijlsma \& Koopman, 2003; Tyler, 2003), keeping a closer relationship and supporting their representatives in their role (Kirkpatrick \& Locke, 1996; Podsakoff, MacKenzie, Moorman, \& Fetter, 1990). However, that is less likely to happen as ERs in some countries (mainly with a Mediterranean style of industrial relations) feel themselves in the middle of tug-of-war. They have to choose between being trusted by management or by his / her co-workers. As mentioned previously in the article, good relations with management are normally detrimental to good relations with co-workers and vice-versa.

However, more collaborative relationships between the actors imply the disappearance of the "them against us" philosophy, which is strongly adopted in some cultures making it more difficult to allow changes. Mutual respect will impulse collaborative relations and a more constructive decision making process with equal level of power between workers and management. As Tjosvold and Chen (2010) concluded "trust is critical for strengthening perceived cooperative goals and mutually beneficial interaction". Therefore, training management, ERs and co-workers about the benefits that trust and mutual respect can have in an organizational and individual level can be a starting point.

\section{Practical implications}

Despite the main theoretical conclusions, the study has interesting practical implications. We include in Table 2 the main suggestions that ERs, union leaders, scholars on the topic and management representatives gave us in order to increase trust in the relationship between ER and management and ER and co-workers (see Table 2). 
Table 2: Practical suggestion for improving the trusty relations inside the European organizations

\begin{tabular}{|c|c|}
\hline $\begin{array}{l}\text { Suggestion to increase trust-based rela- } \\
\text { tions with the management }\end{array}$ & $\begin{array}{l}\text { Suggestion to increase trust-based rela- } \\
\text { tions with your co-workers }\end{array}$ \\
\hline $\begin{array}{l}\text { - Accepting the existence of ER by manage- } \\
\text { ment within the organization and include } \\
\text { them in decision making processes. } \\
\text { - Closer and open communication with } \\
\text { management (i.e. information sharing, mak- } \\
\text { ing suggestion, proposing ideas...). } \\
\text { - No longer "them versus us" philosophy. It is } \\
\text { a shared responsibility. } \\
\text { - Education and learning as basis for dialog } \\
\text { and to be able to analyze the information } \\
\text { provided by the company. } \\
\text { - Talks with management out of the usual } \\
\text { working hours and environment help to im- } \\
\text { prove trust relationships (i.e. when they are } \\
\text { travelling around the world visiting plants). } \\
\text { - Taking seriously the problems that man- } \\
\text { agement communicates ERs and that ERs } \\
\text { communicate to the management: mutual } \\
\text { respect. } \\
\text { - Willingness to compromise. } \\
\text { - Development of collective rights on Euro- } \\
\text { pean dimension will support the improve- } \\
\text { ment of trust based relations. } \\
\text { - More time for union work (i.e. to attend } \\
\text { more courses and be able to understand the } \\
\text { information provided for the decision taking } \\
\text { processes). }\end{array}$ & $\begin{array}{l}\text { - Take the initiative and go out on the floor } \\
\text { to ask employees about their problems and } \\
\text { get feedback about your actions (not wait } \\
\text { sitting in the office). } \\
\text { - Employees should feel that the ER is } \\
\text { protecting them and the usefulness of the } \\
\text { union. } \\
\text { - Maintain confidentiality. } \\
\text { - Be honest and straightforward and give } \\
\text { adequate information. } \\
\text { - Listening to the employees and respect } \\
\text { their opinions. } \\
\text { - Be open with co-workers and explain them } \\
\text { your way of acting (i.e. why you negotiate in } \\
\text { a concrete way). } \\
\text { - Establish networks and newsletter for the } \\
\text { employees to inform them about actions. } \\
\text { - Ask your co-workers to fill in surveys in } \\
\text { order to get feedback about your actions. } \\
\text { - Guide your co-workers in situation in } \\
\text { which they have to go to the HR depart- } \\
\text { ment. } \\
\text { - Develop a stronger trade union basis. }\end{array}$ \\
\hline
\end{tabular}

Although the economical situation nowadays can complicate the "trust building process" and organizational cultures are hardly established, actors involved in these relations can make it happen. Thus, management as well as workers will feel part of the process increasing the real democracy inside organization that today's society claim so much. In that sense, the practical suggestions offered in this work can help to achieve the desired and beneficial trust in industrial relations.

\section{References}

Bacon, N. \& Blyton, P. (1999). Co-operation and conflict in industrial relations: what are the implications for employees and trade unions? The International Journal of Human Resource Management, 10, 638-654.

Bijlsma, K. \& Koopman, P. (2003). "Introduction: Trust within Organisations", Personnel Review, 32 (5), 543-555.

Butler, J.K. Jr (1999). “Trust expectations, information sharing, climate of trust, and negotiation effectiveness and efficiency", Group and Organization Management, 24, 217-238. 
Cook, K.S., Hardin, R., \& Levi, M. (2005). Cooperation without Trust. New York, NY: Rusell Sage Foundation

Costa, A.C., Roe, R.A., \& Taillieu, T. (2001). Trust within teams, the relation with performance effectiveness. European Journal of Work and Organisational Psychology, Vol. 10 (3), pp. 225-44.

De Cremer, D., Snyder, M., \& DeWitte, S. (2001). The less I trust, the less I contribute (or not)? The effects of trust, accountability and self-monitoring in social dilemmas. European Journal of Social Psychology, 31, 93-107

De Dreu, C. K.W., Giebels, E., \& Van de Vliert, E.(1998). Social motives and trust in integrative negotiation: the disruptive effects of punitive capability. Journal of Applied Psychology, 83, 408-422.

Dirks, K.T. \& Ferrin D.L. (2001). The role of trust in organizational settings. Organizational Science, 12, 450-467.

Dirks, K.T. \& Ferrin D.L. (2002). Trust in Leadership: Meta-Analytic Findings and Implications for Research and Practice. Journal of Applied Psychology, 87, 611-628.

Doney, P.M., Cannon, J.P. \& Mulley, M.R. (1999). Understanding the influence of national culture on the development of trust. Academy of Management, 23 (3), 601-620.

Elgoibar, P., Munduate, L., Medina, F.J., \& Euwema, M.C. (2012). Trust: As essential as breathing. In Munduate, L., Euwema, M.C. \& Elgoibar, P. Ten Steps for enpowering employee representatives in the new european industrial relations. Madrid: McGraw Hill.

Elgoibar, P., Euwema, M.C., Munduate, L., Medina, F.J. \& Viemose, S. (2011). "Conflict Management by Worker Representatives in High and Low Power Distance societies". Paper presented at the Industrial Relations in Europe Conference (IREC). September 1-2, Barcelona, Spain.

Euwema, M., Nauta, A., Munduate, L., Medina, F.J., Martinez - Pecino, R. \& Viemose, S. (2008). Empowering Negotiators: Creating Sustainable Motivation byProviding Job Resources for Union Representatives. Symposium presented at the International Association of Conflict Management Conference (IACM), July 3-6, Chicago, Illinois, available at http://www.iacm-conflict.org/2008/May30_Print Final_IACM\%202008\%20Program. pdf (accessed 10 August 2010).

Ferrin, D.L., Bligh, M.C. \& Kohles, J.C. (2007). A theory of trust, monitoring and cooperation in interpersonal and intergroup relationship. Group and Organization Management, 32, 465-49.

Friedman, R.A. (1993). Bringing mutual gains bargaining to labor negotiations: the role of trust, understanding and control. Human Resource Management, 32, 435-459.

Gambetta, D. (1988). Can we trust? In D. Gambetta (Ed.), Trust: Making and breaking cooperative relations. 213-238. New York: Blackwell.

Hyman, R. \& Ferner, A. (1994). New Frontiers in European Industrial Relations. Oxford, UK: Blackwell business.

Hyman, R. (1994). Industrial Relations in Western Europe: An era of ambiguity? Industrial Relations, 33 (1), 1-24.

Hyman, R. (1995). Industrial Relations in Europe. Theory and Practice. European Journal of Industrial Relations, 1 (1), 17-46.

Hofstede, G. (1997). Cultures and organizations: Software of the mind. New York, NY: McGraw Hill.

Hofstede, G.H. (2001). Culture's consequences, second edition: comparing values, behaviors, institutions and organizations across nations. California, CA: Thousand Oaks Sage. 
House, R.J., Hanges, P.J., Javidan, M., Dorfman, P.W. \& Gupta, V. (2004). Culture, leadership, organizations. London, UK: Thousand Oaks Sage.

Hyman, R. (1994). Industrial Relations in Western Europe: An era of Ambiguity? Industrial Relations, 33 (1), 1-24.

Kimmel R.M. \& Tyler T. R. (1996). Trust in organizations. Frontiers of Theory and Research. London, UK: Sage.

Kimmel M., Pruitt D., Magenau J., Konar - Goldband, E. \& Carnevale, P. (1980). Effects of trust, aspiration and gender on negotiation tactics, Journal of Personality and Social Psychology, 38, 9-22.

Kirkpatrick, S. A., \& Locke, E. A. (1996). Direct and indirect effects of three core charismatic leadership components on performance and attitudes".Journal of Applied Psychology, 81, 36-51.

Kramer, R.M. (1999). Trust and distrust in organizations: emerging perspectives, enduring questions. Annual Review of Psychology, 50, 569-598.

Kramer, R.M. \& Cook, K.S., (2004). Trust and distrust in organizations: dilemmas and approaches. New York, NY: Sage.

Lewicki R.J., McAllister D.J. \& Bies, R.J. (1998). Trust and distrust: new relationship and realities. Academy of Management Review, 23, 438-458.

Martinez-Lucio, M. \& Stuart, M. (2005). Partnership and new industrial relations in a risk society: and age of shotgun weddings and marriages of convenience? Work, employment and society, 19, 797-817.

Mayer, R.C., Davis, J.H. \& Schoorman, F.D. (1995). An integrative model of organizational trust. Academy of Management Review, 20, 709-734.

Mc Evily, B., Perrone, ,V. \& Zaheer, A. (2003). Trust as an Organisational Principle. Organizational Science, 14 (1), 91-103.

Mooradian, T., Renzl, B. \& Matzler, K. (2006). Who trust? Personality, Trust and Knowledge sharing. Management Learning, 4, 523-540.

Munduate, L., Ganaza, J., Alcaide, M. \& Peiró, J.M. (1994). Spain. In A. Rahim and A.A. Blum (Eds.), Global Perspectives on Organizational Conflict, pp. 103-134. Westport, CT: Praeger Publishing.

Munduate, L., Barón, M. \& Luque, P. (1997). Styles of handling interpersonal conflicts. Psycothema, 9 (1), 145-153.

Munduate, L., Ganaza, J., Peiró, J.M. \& Euwema, M. (1999). Patterns of styles in conflict management and effectiveness. International Journal of Conflict Management, 10, 5-24.

Munduate, L., Euwema, M.C., \& Elgoibar, P. (2012). Ten Steps for empowering employee representatives in the new european industrial relations. Madrid: McGraw Hill.

Podsakoff, P., MacKenzie, S., Moorman, R., \& Fetter, R. (1990). Transformational leader behaviors and their effects on followers' trust in leader, satisfaction, and organizational citizenship behaviors. Leadership Quarterly, 1, 107-142.

Pruitt, D. G. \& Carnevale, P.J. (1993). Negotiation in Social Conflict, Pacific Grove, CA: Brooks/Cole.

Rocha, S.R. (2010). Shop stewards as coordinators of employee-driven innovation (EDI): implications for trade unions. Transfer: European Review of Labour and Research, 16, 185-196.

Rousseau, D.M., Sitkin, S.B., Burt, R.S., \& Camerer, C. (1998). Not so different after all: a cross discipline view of trust. Academy of Management Review, 23 (3), 393-404.

Stuart, M., \& Martinez - Lucio, M. (2002). Social Partnership and the Mutual Gains Organization: Remaking Involvement and Trust at the British Workplace. Economic and Industrial Democracy, 23, 177-200. 
Tyler, T.R. (2003). Trust within Organisations. Personnel Review, 32 (5), 556-568.

Tyler, T., \& Degoey, P. (1996). Trust in organizational authorities, the influence of motive attributions on willingness to accept decisions. In Kramer, R.M. and Tyler, T.R. (Eds), Trust in Organizations: Frontiers of Theory and Research, 331-57. London UK: Sage.

Van Oudenhoven, J.P., Mechelse, L., \& De Dreu, C. (1998). Managerial conflict managmenet in Five European Countries: The importance of power distance, uncertainty avoidance and masculinity. Applied Psychology: An International Review, 47, 439-455.

Zaheer, A., Mc Evily B., \& Perrone, V. (1998). Does trust matter? Exploring the effects of interorganizational and interpersonal trust on performance. Organization Science, 9, 141-159.

\section{As relações laborais na Europa são baseadas na confiança? A perspectiva dos representantes sindicais.}

Numerosos investigadores provenientes de várias disciplinas concordam em que a confiança gera benefícios importantes tanto para as organizações (Dirks \& Ferrin, 2001) como para seus membros (Kramer, 1999). No entanto, algumas vezes não é fácil alcançar o nível de confiança valorizado e desejado nas relações laborais. Neste artigo, em primeiro lugar, analisamos o conceito de confiança e sua importância no âmbito das relações laborais Europeias. Em segundo lugar, exploramos como os representantes sindicais (ER) na Europa percebem a sua relação com a Direcção bem como com os seus colegas de trabalho, com foco no papel da confiança. Finalmente, concluiremos com uma discussão e algumas recomendações práticas que podem ajudar aos ER a fomentar relações mais confiáveis, contribuindo dessa maneira para melhorar a sua capacidade de participação em processos de tomada de decisão e, consequentemente, para um estilo de gestão do conflito mais construtivo.

PALAVRAS-CHAVE: Confiança, representantes sindicais, relações laborais, Direcção, colegas de trabalho. 